\title{
パルスグリーンレーザーアニール用均一線状ビーム照射光学系の開発
}

\author{
岡本 達樹，森川 和敏，園 淳弘，佐藤 行雄 ${ }^{\dagger}$, 西前順一
}

三菱電機(株) 先端技術総合研究所 ( $=661-8661$ 兵庫県尼崎市塚口本町8-1-1)

\section{Development of Line-shaped Optical System for Pulsed Green Laser Annealing System for Manufacturing of Low-Temperature Poly-Si TFT}

\author{
Tatsuki OKAMOTO, Kazutoshi MORIKAWA, Atsuhiro SONO, Yukio SATO,$^{\dagger}$ and Junichi NISHIMAE \\ Mitsubishi Electric Corporation Advanced Technology R \& D Center, 8-1-1 Tsukaguchi-honmachi, Amagasaki, Hyogo 661-8661
}

(Received July 14, 2005)

\begin{abstract}
We have developed a new optical system that transforms the circle profile beam generated with near Gaussian intensity distribution by a pulsed green laser (second harmonics of a Q-switched Nd:YAG laser) into a lineprofile beam. This transformed beam has uniform distribution to within $5 \%$ in the longitudinal direction, and is about $100 \mathrm{~mm}$ long and $40 \mu \mathrm{m}$ wide. In the width direction, the laser beam is focused to the limited $\mathrm{M}^{2}$ value. For homogenization in the longitudinal direction, we employ a one dimensionnal waveguide plate type homogenizer. The laser beam is divided by waveguide plates, and the divided beams are overlapped on the surface of the works. We successfully reduced interference fringes by increasing the fixed optical pass difference beyond the inherent time and coherent length for every divided pair of adjacent beams under a controlled space coherent length.
\end{abstract}

Key Words: Nd:YAG laser, Second harmonics, Polycrystalline silicon, Laser annealing, Line-shaped beam, Interference fringes

1.はじめに

高性能な液晶ディスプレイ(LCD), 有機ELディスプレ イ(OLED)を作成するために低温多結晶シリコン (LTPS) 薄膜トランジス夕 (TFT) は必要である。TFTの製作のた めにアモルファスシリコン $(\mathrm{a}-\mathrm{Si})$ 薄膜を多結晶シリコン (poly-Si) 薄膜に結晶させるために, 生産ラインでは, 一般 にレーザーアニール技術が使われている。現在レーザー アニールでは, 紫外線の波長領域で発振するエキシマ レーザーで，308 nmの波長で発振するXeClレーザーが光 源として一般的に使われている1,2). しかしながらアニー ル特性としてレーザー照射エネルギーに対する移動度の 変化が大きく，わずかなレーザーエネルギの変動に対し て移動度が大きく变化するということが問題となってい る。例えば，T. Ogawaら ${ }^{2)}$ は，エキシマレーザーアニール の場合, 照射エネルギーが5\%変動すると移動度が90\%に 低下すると報告している。この結果, 一定の移動度を得 るために定期的な照射エネルギーの調節が必要になると ともに, 生産工程において歩留まりが上がらないという 大きな問題が生じている。また，エキシマレーザーは， 紫外線レーザーであり, 高電圧印加によるパルス発振を 行うガスレーザーである。紫外線レーザーであることか
ら，レーザー空の量りに対する交換保守，レーザーガス 交換の保守，電極劣化によるレーザー本体の入れ替え 等, 大きな保守時間, 保守コストが必要になり, TFTを量 産するうえでの大きな問題となっている.

これらの問題を解決するために，エキシマレーザーに 代わるレーザーとして注目されるのは, 半導体レーザー 励起のNd: YAGレーザーの第2高調波により得られるパル スグリーンレーザー光 (波長 $532 \mathrm{~nm}$ )を光源とするアニール 装置3)である。 パルスグリーンレーザーを使うと一定の照 射エネルギーに対しエキシマレーザーに比べ広いプロセ スマージンが得られる。これは, 紫外光であるエキシマ レーザー光が, a-Si薄膜の表面のみで吸収され, 冷却時に ガラス基板側に残されたシリコンの微結晶を核として結 晶成長するので, 照射エネルギーの調節により溶融量を 調節する必要があるのに対し，パルスグリーンレーザー 光は, a-Si薄膜を透過するためシリコン膜全体が溶融し, 溶融したシリコンと未溶融のシリコンの境界から結晶成 長するので, 照射エネルギーによる溶融量の調節が不要 なためである。さらに，パルスグリーンレーザーは固体 をレーザー媒質としガスレーザーではないため, 日常の ガス交換は必要としない. また，可視光を光源とするた め，紫外線のように有機ガスを分解してレーザー光取り

垷在の所属：三垚電機（株）名古屋製作所（† 461-8670 愛知県名古屋市東区矢四南 5-1-14）

†Present address: Mitsubishi Electric Corporation Nagoya works, 5-1-14 Yataminami, Higashi-ku, Nagoya, Aichi $461-8670$ 
出し空に薄膜が堆積することもなく, レーザー空に対す るクリーニング等の日常保守も必要としない.さらに レーザー本体の入れ替えといった大掛かりな保守を必要 とせず，結果的に保守に必要な維持費用が低減できる利 点がある4). エキシマレーザーで用いられている線状ビー ム光学系は, 2次元のホモジナイザにより, ビーム強度分 布を均一化している。パルスグリーンレーザーは，エキ シマレーザーに比ベビーム品質が良いため, 線状ビーム の幅方向について，ホモジナイザで均一化することな く，レーザービームの $\mathrm{M}^{2}$ 值で決まる限界まで集光するこ とにより，薄膜上での光強度を高めることができる。一 方，パルスグリーンレーザーは，エキシマレーザーに比 べ可干渉性が高いため, 干渉縞の発生により, 長手方向 の強度分布が乱される。パルスグリーンレーザーアニー ルは, エキシマレーザーアニールに比ベプロセスマージ ンが広く, 移動度が90\%に低下する照射エネルギー変動 は12\%2)であるが, 干渉縞が発生するとそれ以上の強度分 布が発生してしまい, 均一な結晶を得るのが困難であっ た。そこで，本報告では，パルスグリーンレーザー発振 器から出力されるガウス強度分布を持つ円形のビームを 均一な強度分布を持つ線状ビームにするための新しい光 学系について述べる.

\section{2. パルスグリーンレーザーアニールシステム}

Fig. 1にパルスグリーンレーザーアニールシステムの概 略構成図を示す。パルスグリーンレーザー(波長：532 $\mathrm{nm})$, ビーム成形光学系, X-Yステージで構成される。 ビーム成形光学系では, パルスグリーンレーザーから放 出されたガウス分布の円形ビームを線状ビームに変換す る.ビーム成形光学系は, レンズの焦点距離等, 光学パラ メータの変更で, 色々な線状ビームサイズに対応する.

Table 1に光学系の仕様を示す. 本光学系は最大 $100 \mathrm{~mm}$ $\times 40 \mu \mathrm{m}$ の線状ビームを成形でき, YAG $2 \omega$ レーザー発振器 出力が $50 \mathrm{~mJ} / \mathrm{pulse}$ のき, 最大 $800 \mathrm{~mJ} / \mathrm{cm}^{2}$ 以上のエネル ギ密度で照射することができる。

Fig. 2にパルスグリーンレーザーアニール光学系の全体

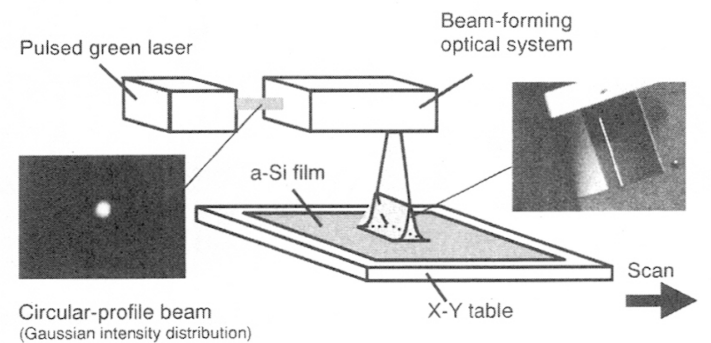

Fig. 1 Schematic diagram of pulsed green laser annealing.

Table 1 Specifications of pulsed green laser annealing lineprofile beam.

\begin{tabular}{|c|c|c|c|}
\hline \multicolumn{2}{|c|}{ line-profile beam parameter } & \multicolumn{2}{|c|}{ Specifications } \\
\hline \multirow{2}{*}{ Beam size } & Width (a) & $40 \pm 10 \mu \mathrm{m}$ & FWHM \\
\hline & Longitudinal direction (b) & $=100 \mathrm{~mm}$ & FWHM \\
\hline \multicolumn{2}{|c|}{ Longitudinal direction beam uniformity } & $= \pm 5 \%$ & $10 \%-90 \%$ \\
\hline
\end{tabular}

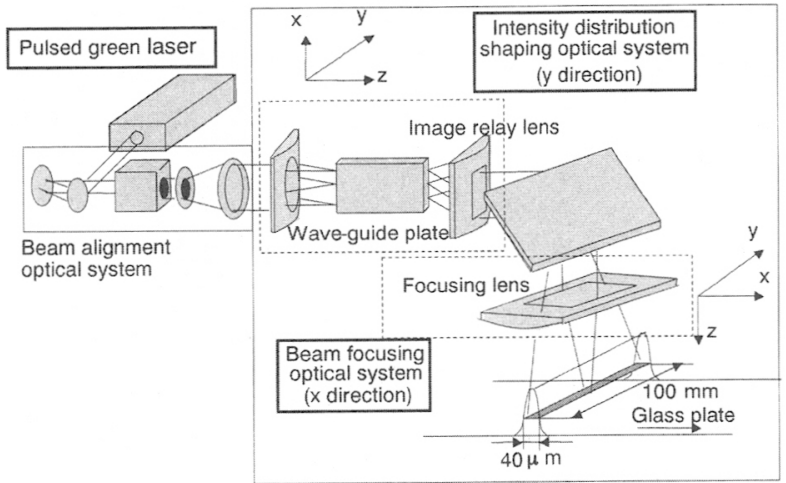

Beam - forming optical system

Fig. 2 Optical system for pulsed green laser.

ブロック図を示す。ここで, 光軸を $z$ 方向とし, ガラス基 板上の薄膜に照射する線状ビームの幅方向老 $x$ 方向, 長手 方向を $y$ 方向と定義する。

光学系は, レーザービーム導入光学系, ビーム成型光 学系(ビーム強度均一化光学系 ( $y$ 方向), ビーム集光照射光 学系 $(x$ 万向 $))$ に大き分かれる. ビーム導入光学系は, レーザー発振器からのレーザービームの光軸位置, 角度 を調整し, 可変アッテネータによりレーザーの照射パ ワーを調節する。アニール光学系全ての光学素子の損失 を含めて, レーザー発振器出力の $6 \%$ ～ $65 \%$ の範囲で調節 可能である. さらに, ビーム成型光学系のx方向集光光学 系により所望の集光ビーム幅を得るため, レーザービー ムの $\mathrm{M}^{2}$ 值にあわせて, ビーム成型光学系に入射するレー ザービームのビーム径を調節する。

ビーム成型光学系は, ビーム集光照射光学系により, 線状照射ビーム $x$ 方向に対し, レーザー光の $\mathrm{M}^{2}$ 值で規定さ れる限界までレーザービームを集光する。一方，ビーム 強度均一化光学系 $(y$ 万向 $)$ により，線状照射ビーム $y$ 万向に 対し, 導波路型ホモジナイザによりビーム強度分布を均 一化し, 線状の照射ビームパターンを成型するための光 学系である. 次章でビーム成型光学系の詳細について述 ベる.

\section{3. ビーム成型光学系}

\section{1 ビーム集光照射光学系 $(x$ 方向 $)$}

Fig. 3にビーム集光照射光学系の構成を示す.レーザー ビーム導入光学系により成型されたレーザービームは, ビーム拡大レンズにより幅が拡大され，xコリメートレン ズにより平行光にされ，折り返しミラーで反射された

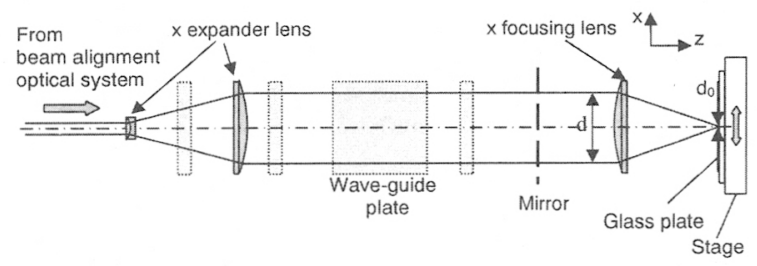

Fig. 3 Arrangement of beam focusing optical system (x direction). 
後, 集光レンズでガラス基板上に集光される.ここで, レーザービームは導波路構造のホモジナイザを通過する が，ホモジナイザは1次元構成であるので， $y$ 方向にのみ作 用する， $x$ 方向に関しては作用しないため，(1)式で示すよ うに， $x$ 集光レンズの焦点距離， $x$ 集光レンズに入射する レーザービームの幅とレーザー光の $\mathrm{M}^{2}$ 值で規定される幅 まで集光できる.

$$
d_{0}=\mathrm{M}^{2} \frac{4 \lambda}{\pi d} f
$$

$$
d_{0} \text { : 集光幅 }\left(1 / \mathrm{e}^{2} \text { 全幅 }\right) \quad \mathrm{M}^{2}: \mathrm{M}^{2} \text { 值 } \lambda \text { : 波長 }
$$

$d$ : 集光レンズ入射ビーム幅 $\left(1 / \mathrm{e}^{2}\right.$ 全幅 $) f$ : 集光レンズ 焦点距離

例えば， $\mathrm{M}^{2}=20, \lambda=532 \mathrm{~nm}, d=80 \mathrm{~mm}$ (1/ $\mathrm{e}^{2}$ 直径)， $f=300 \mathrm{~mm}$ とすと，

$$
d_{0}=51[\mu \mathrm{m}]\left(1 / \mathrm{e}^{2} \text { full width }\right)
$$

となり, FWHM(半值全幅)は,

$$
d_{n}=\operatorname{In}(2) \times d_{0}[\mu \mathrm{m}](\mathrm{FWHM})
$$

となる。

実際には， $x$ 集光レンズの幾何学的な収差があり, 集光 幅は，約40 $\mu \mathrm{m}$ (FWHM) になる。すなわち，集光幅は， レーザー発振器のビーム品質によって決まり， $\mathrm{M}^{2}=20$ 以 下のレーザービームであれば，約 $40 \mu \mathrm{m}$ 幅(FWHM)まで集 光することができる.

なお，(1)式からわかるように，集光前のレーザービー ム幅を変更することにより, レーザー発振器の変更等に 伴う $\mathrm{M}^{2}$ 值の変化に対応できる.

\section{2 ビーム強度均一化光学系 $(y$ 方向 $)$}

ビーム強度分布の均一化は，1次元の導波路型のホモジ ナイザによりレーザービームを断面方向で分割し, 分割 されたレーザービームを転写レンズによりガラス基板上 の薄膜上に重ね合わせることにより行う．Fig. 4にビーム 強度分布均一化光学系の構成を示す.レーザービーム導 入光学系で成型されたレーザービームは，ビーム拡大レ ンズとyコリメートレンズによりビーム幅が拡大され，y集 光レンズにより導波路型ホモジナイザに絞りこまれなが ら入射される。ここで， $y$ 集光レンズの焦点距離および ビーム幅は, 導波路型ホモジナイザで, ビーム強度分布 に必要なNAになるよう設定する。導波路型ホモジナイザ

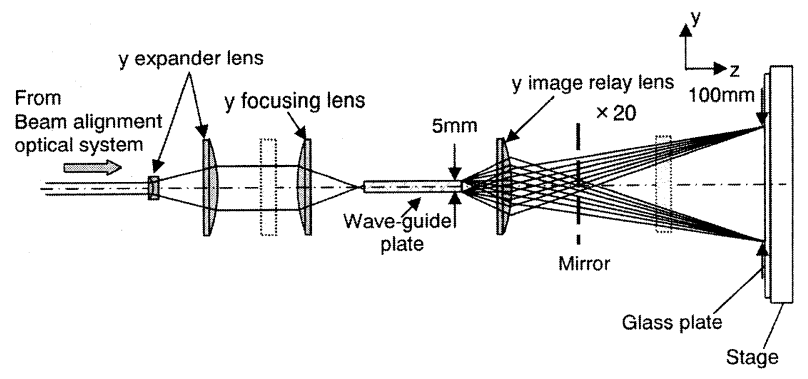

Fig. 4 Arrangement of an intensity distribution shaping optical system (y direction).
では，およそ7８個の短冊状のビームに分割される，導 波路で分割されたレーザービームは，導波路出口で重な り，均一な強度分布になるが，導波路を出たあと別々の 方向に広がっていく、それらのレーザービームを転写レ ンズでまとめ，折り返しミラーを経てガラス基板上に導 波路出口の像を拡大転写することにより，ガラス基板上 で均一な強度分布を得ることができる．本光学系では， 20倍の拡大転写が可能で， $5 \mathrm{~mm}$ 幅の導波路を用いるとガ ラス基板上で $100 \mathrm{~mm}$ (FHHM) 程度の長さの線状ビームが 得られる。

\section{4. 干渉による強度分布変化と干渉抑制方法}

4.1 導波路型ホモジナイザによる強度分布均一化時 の干渉縞の発生

Fig. 5にレーザービームが導波路入射面に対して垂直に 入射する場合の導波路によるビームの分割の様子を示す.

例えば，導波路で，入射ビームが7分割される場合を考 える。導波路で分割される前の入射ビームを導波路内で の反射回数別に $\mathrm{A} \sim \mathrm{G}$ の成分に分ける. 垂直入射導波路で は，入射ビームの外側であるA，Gが導波路の反射面に対 して大きな角度を持って入射するため，導波路内での反 射回数が多い．また，入射ビームの中心部であるDは，導 波路の反射面で反射されることなく，導波路から反射さ れる，導波路から出射されるビームは，反射されない成 分Dを中心として，奇数回反射される成分 $\mathrm{A}, \mathrm{C}, \mathrm{E}, \mathrm{G}$ が 入射ビームと同じ方向に並び，偶数回反射される成分 $\mathrm{B}$, Fが入射ビームと反転し，逆方向に奇数回反射ビームの間 に並ぶ。すなわち，導波路の出射面では，互いに隣接す る分割ビームが折り返されて重畳される。いま，入射 ビームの空間的な干渉距離が，導波路での分割幅より短 い場合でも，レーザービームの分割前に互いに隣接する 成分は，その境界が，導波路の出射面での端部で一致す る。従って，このような折り返した分割ビームを， $y$ 転写 レンズと $x$ 集光レンズを介して，ガラス基板上に重ね合わ せて投影すると，照射面上で分割ビームが干渉し，縞状 の強度分布が形成される。

本光学系では，導波路から放出されたビームが，y転写 レンズの焦点位置で, 反射回数の異なるビームが空間的 に分離する. Fig. 6は, 導波路で分割されたビームの2成分 のみを切り出し, 照射ビームの長手方向の強度分布を測 定した結果である。(a)が，隣接する分割ビームであるC とDを重ね合わせた場合，（b）は，隣接していない分割

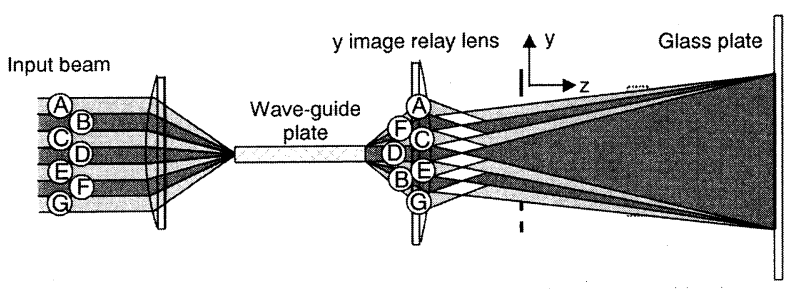

Fig. 5 Beam homogenization in perpendicular incidence waveguide plate. 


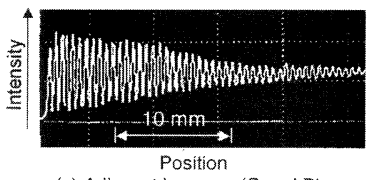

(a) Adjacent beams (C and D)

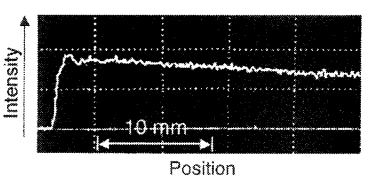

(b) Nonadjacent beams ( $\mathrm{C}$ and $\mathrm{E})$
Fig. 6 Interference fringes produced by pair of adjacent beams compared with that of nonadjacent beams.

ビーム同士，ここでは，CとEを重ね合わせた場合であ る。（a）では，干渉により干渉縞が発生し，強度分布が大 きく変化している，特に，分割前に距離近かった端部 で，その影響は顕著である。また，干渉縞の振幅は，照 射ビームの中心に向かって減衰する。この減衰が，入射 レーザービームの空間的可干渉距離に関係する。一方,

(b)では，干渉縞が発生して㧍らず，入射レーザービーム の空間的可干渉距離以上離れていることがわかる。この ように，照射ビームに干渉縞が発生するため，長手方向 に均一な強度分布が得られず, 均一な粒径の結晶が得ら れない。

\section{2 導波路型ホモジナイザにおける干渉縞の抑制}

隣接する分割ビーム同士を干渉させないために，一方 の分割ビームに時間的な可干渉距離以上の時間的遅延を おこなう方法を検討する。

レーザービームの時間的可干渉距離 $\Delta L$ は，レーザーの 波長とスペクトル幅で定義され，パルスグリーンレー ザー(YAGレーザーの第二高調波)では， $\Delta L$ は， $\Delta L=4$ 〜 $10 \mathrm{~mm}$ となる。実際に, レーザービームの時間的可干渉距 離を測定したところ，干渉縞のビジビリティが5\%以下と なるのは， $\Delta L=12 \mathrm{~mm}$ であった。石英ブロックにより， 可干渉距離相当の光路差を設けるためには $L=24 \mathrm{~mm}$ 以上 の厚みにする必要がある. 奇数回反射の成分を偶数回反 射の成分に対して時間的遅延をかければよい，例えば，

Fig. 7に示すように，導波路で分割されたビームが扔互い に分離する位置に交互に石英ブロックを配置すれば，照 射ビーム上での干渉縞の発生は抑制できる。しかし，実 際の光学系では, 分離された分割ビームの間隔が狭く, 石英ブロックを配置できない。

分割された導波路から出射されたビームに対し, 交互 に石英ブロックを設置する必要があるのは, 導波路内で 反射されない成分 $(\mathrm{D})$ が存在するためである。 そこで, 導 波路内を，反射することなく直進する分割ビームを含ま ないように，全ての分割ビームが少なくとも一回は反射

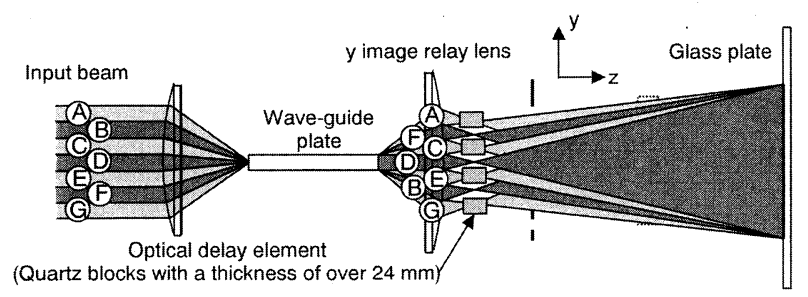

Fig. 7 Reduction of interference fringes for waveguide plate homogenizer.
するように導波路によりレーザービーム分割する。その ためにはFig. 8に示すように，導波路の中心軸に対して， 導波路の入射面を傾けることによって実現できる。いわ ゆる斜め入射面導波路を用いる.

導波路の入射面を傾けることによって, 導波路に入射 するビームが曲げられ，Fig. 9に示すように斜めからレー ザービームが入射された構成と同じ状態になり, 分割前 に隣接する分割ビームである導波路内で奇数回反射する 成分と偶数回反射する成分が，導波路の中心光軸を挟ん で分離する，従って，例えば奇数回反射の分割ビームの 光路に, 石英ブロックを設置し, 光学的な遅延を設ける ことで，隣接する分割ビームに対して全て時間的可干渉 距離より大きな遅延をかけられるので, 干渉が起こら ず，干渉縞が発生しない。

Fig. 10に本構成による分割ビームの重ね合わせ時の均一 化方向強度分布を示す. (a) は, 照射ビームの強度分布で あり, 光学的遅延素子である石英板の扦入により, 干渉 縞の発生が抑制され，干渉による強度分布の変動がない ことがわかる.また，(b)は，ビーム照射後のポリシリコ ン結晶を光学顕微鏡で観測した写真である．照射ビーム に干渉縞がある場合，局部的に照射強度が高くなるので 変色しており，均質なポリシリコン結晶が生成されてい ない。一方，石英板の挿入により，局部的な変色はな く，均質なポリシリコン結晶が生成されていることがわ かる.

\section{5. 結 果}

Fig. 11に, 本光学系により得られた線状ビームのプロ ファイルを示す。（a) は幅方向 $(x)$, (b) は長手方向 $(y)$ であ る。ビーム形状は， $105 \mathrm{~mm} \times 38 \mu \mathrm{m}(\mathrm{FWHM})$ である。ま た, 長手方向のビーム均一性は, $3 \%$ 以内で, 均一領域 は, $102 \mathrm{~mm}$ である。仮に，パルス出力50 mJのパルスグ リーンレーザー発振器を用いると, 最大 $800 \mathrm{~mJ} / \mathrm{cm}^{2}$ のエネ ルギー密度で照射できる。

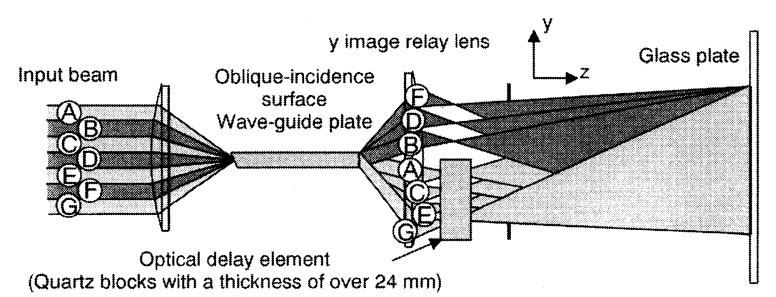

Fig. 8 Reduction of interference fringes with oblique-incidence surface waveguide plate.

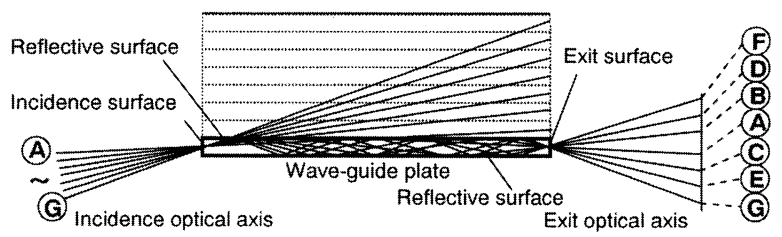

Fig. 9 Developed view of Oblique-incidence surface waveguide plate. 

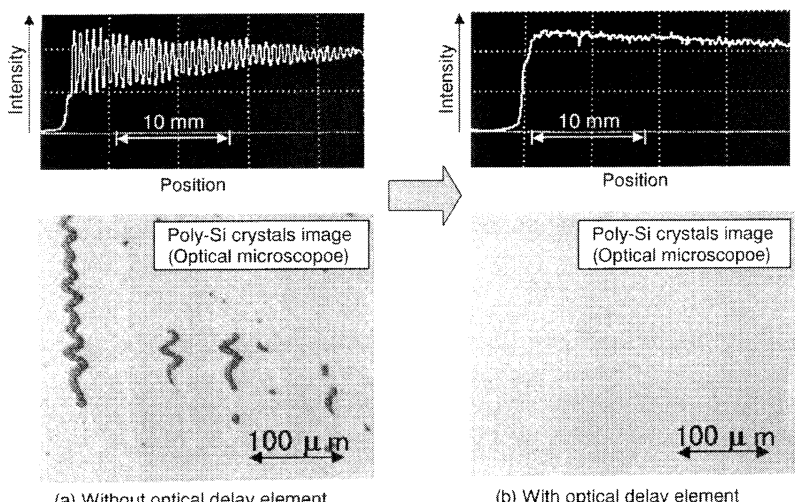

(a) Without optical delay element

(b) With optical delay element
Fig. 10 Result of reducing interference fringes.

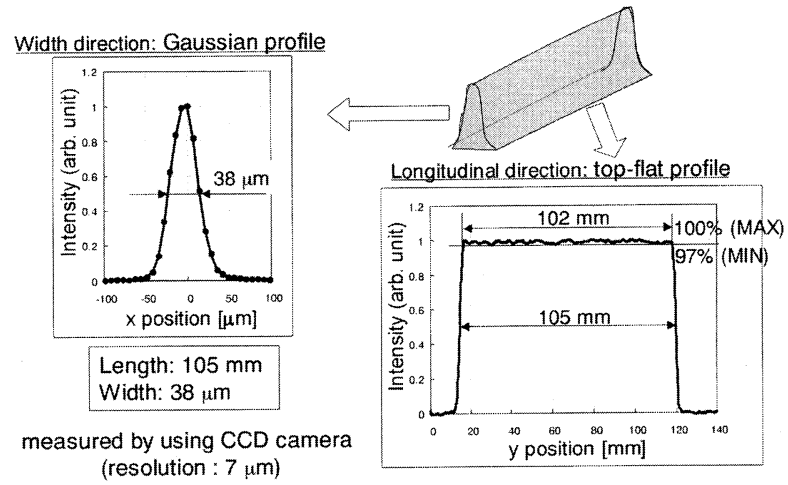

Fig. 11 Beam profile obtained with developed optical system.

\section{6. まとめ}

パルスグリーンレーザー用アニール光学系として，発 振器から放出されるガウス強度分布に近い円形ビームを 均一なラインビームに変換する光学系を開発した．ライ ンビームの幅方向は, レーザービームの $\mathrm{M}^{2}$ 值で決まる最 小幅まで集光し，薄膜上で光強度を最大化した。一方， 長手方向は，エキシマレーザーより干渉性が高いパルス グリーンレーザービームに対し，導波路で均一化する際 に干渉する成分に光学的遅延を加えることにより，干涉 縞の発生を抑制することで，均一な強度分布を得た。

これにより，エキシマレーザーより維持費用が低減で きるパルスグリーンレーザーへの置き換え，さらには， パルスグリーンレーザーを用いた高品質TFTを量産する生 産ラインへの適用が可能になる。

\section{参考文献}

1) N. Matsuo, Y. Aya, T. Kanamori, T. Nouda, H. Hamada, and T. Miyoshi: Jpn. J. Appl. Phys. 39 (2000) 351.

2) T. Ogawa, H. Tokioka, K. Furuta, Y. Sato, M. Inoue, S. Yagi, M. Miyasaka, S. Inoue, and T. Shimoda: EuroDisplay '99 Late news paper (1999) p. 81.

3) K. Tamagawa, H. Ikeda, T. Ohnishi, K. Kuwahara, M. Kikuchi, M. Hayama, and K. Nakamura: IDW '03 Digest (2003) 585.

4) K. Morikawa, T. Okamoto, T. Kojima, S. Yura, J. Nishimae, Y. Sato, M. Inoue, and H. Nagata: SID '04 Digest (2004) 1088. 